\title{
Genotypes by environment effect on flowering and seed set in cassava, Manihot esculenta Crantz in Uganda
}

\author{
Lado Aquilino $^{1,3 *}$, A.Pariyo ${ }^{2}$, Y.Baguma ${ }^{2}$, R.Edema ${ }^{1}$, P.Gibson ${ }^{1}$ and J.Bisikwa ${ }^{1}$ \\ ${ }^{1}$ College of Agricultural and Environmental Sciences, Makerere University, P.O. Box 7062 Kampala, Uganda; ${ }^{2}$ National Crops Resources Research \\ Institute, Namulonge, Roots Crops Program, P.O. Box 7084 Kampala, Uganda, ${ }^{3}$ Directorate of Research, Ministry of Agriculture and Food Security, \\ Ministries Complex, Parliament Road, P.O.Box 33, Juba, South Sudan
}

(Received: November 18, 2019; Revised: July 12, 2021; Accepted: July 20, 2021; Published: August 14, 2021)

*Corresponding author: Lado Aquilino(E-mail: aquilinowani@yahoo.com)

\begin{abstract}
Cassava (Manihot esculenta Crantz) production has been constrained by biotic and abiotic factors, which could be solved by conventional breeding. However, cassava hybridization is difficult because many genotypes do not flower or set seeds and yet cassava sexual reproduction is essential for breeding programs. Consequently, this study was undertaken to identify agro ecologies in Uganda that best promote cassava flowering and seed set in order to facilitate breeding. Field evaluation of eight genotypes in randomized complete block design with three replications at three agro-ecologies of Uganda for two cropping seasons was conducted. Weather data were monitored and cassava flowering/seed set-related traits were collected at one-month interval commencing from 1.5 Months after planting. Results indicated that varieties previously categorized as high flowering and seed set performed differently than those identified as poor flowering and seed set, although with varying genotypic differences in each environment. Genotypes mean performances, additive main effect and multiplicative interaction and genotype main effect and genotype by environment interaction bi-plots model' results indicated Rwebitaba in Western savannah grassland agro-ecology and Namulonge-NaCRRI in Lake Victoria Crescent agro-ecology as the most favorable environments for the performance of all the evaluated traits, and season one as the most favorable season. However, the most stable environment for all the evaluated traits was Abi-ZARDI. Conclusively, the high proportion of variation which occurred between genotypes and environments was explained by the genotypic variances. Dry months had poorer cassava flower initiation and development than wet months of the cropping season. Therefore, Abi-ZARDI in North-western savannah grassland agro-ecology and season one could be recommended for the establishment and timing of cassava breeding nursery.
\end{abstract}

Key words: GEI, AMMI analysis, flower initiation, cropping season

\section{INTRODUCTION}

Cassava (Manihot esculenta Crantz) is a vitally important food source for many people in developing tropical countries, and has a lot of significant opportunities for improvement such as pests and diseases resistance, nutritional compositional qualities, and agronomics traits which conventional and modern biotechnology is expected to play an important role. However, although cassava plays an important role as food crop in the tropical regions of the world, its genetic improvement has lagged considerably behind compared to other staples crops such as maize and rice (Ceballos et al., 2004). A major limitation to cassava rapid genetic improvement has been identified as poor flowering ability and seed set, due to several reasons including a long and variable juvenile phase before flower initiation, insufficient flower numbers and high rates of flower abortion following pollination (Jennings \& Iglesias, 2002). Seasonal changes in temperature and humidity greatly influence flowering in cassava, especially the ability of flowers to mature and open for effective pollination (Olasanmi et al., 2014).

A wider environmental variability such as that of Uganda would be of particular interest to cassava breeding. This is because, Uganda has eleven agro-ecological zones, each with distinct environmental characteristics (Jaetzold \& Schmidt, 1983). These inevitably affects phenotypes of quantitative traits in cassava (Egesi et al., 2007). Therefore, for effective optimization of resources invested in breeding programs, knowledge of actual effect of specific environment on performance of genotypes for particular trait is paramount. This is why, eight cassava genotypes distinct in its flowering and seed set related traits attributes and known for good agronomics traits (Fresh roots yield, dry matter contents and harvest index) were screened in three environments of Uganda in two cropping seasons for flowering and seed set related traits performances.

According to Alves (2002), cassava can be grown in diverse agro-ecologies which differ in rainfall, temperature regimes and soil types and that the variation among ecozones and seasonal changes in one zone may also be very large. This causes the expression of individual phenotypes to be determine by both the genotype and the environment. GEI is a result of inconsistent performances of genotypes across environment, and significant GEI results from changes in the magnitude of differences between genotypes in different 
environment or from change in the relative ranking of the genotypes (Fernandez, 1991), and that genotypes whose GEI is insignificant are said to be stable, contrary to a significant GEI which usually presents limitations in the selection of the superior genotypes. And this reduces the usefulness of the subsequent analysis of means and the inferences that would otherwise be valid (Shaff et al., 1992), because there will not be selection of the superior genotypes but rather recommending that genotype for multi-environments trials. In order to overcome the challenge of GEI, breeders have to evaluate genotypes in several environments to ensure they select genotypes with high and stable performance. Several biometrical methods had been developed and used to analyze GEI, stability and adaptability. In this study in addition to conventional ANOVA, AMMI and GGE bi-plot models were preferred. Conclusively, the purpose of this study was to identify agro-ecologies in Uganda that best enhance cassava flowering and seed set in order to facilitate cassava hybridization in Uganda. Specifically, to determine the performance of flowering and seed set in cassava genotypes across different agro-ecologies and cropping seasons.

\section{MATERIALS AND METHODS}

\section{Experimental genotypes}

Eight cassava genotypes, four improved and four landraces, known for good agronomic traits were screened in three sites of Uganda. The experimental genotypes were purposely selected and grouped into four groups based on flowering and seed set attributes (1) High flowering and seed set, (2) High flowering and no seed set, (3) Poor flowering and seed set, and (4) Hardly flower most of the time genotypes (NaCRRI cassava scientists' personal communications) (Table1). All the experimental genotypes were CBSD, CMD \& CGM disease symptomless cassava planting materials collected from Eastern and Central part of Uganda.

\section{Field experiments}

Subsequent field experiments were conducted in two cropping seasons. May 2014/May 2015 considered as season one and Nov.2014/Nov.2015 considered as season two. Both seasons were planted in three agro-ecologies in Uganda, with each season considered as environment, giving a total of six environments (Table 2).

Namulonge is located in Wakiso District, a few kilometers $(96 \mathrm{k} \mathrm{km})$ away from the equator in Uganda, and had the mean annual rainfall and temperature of $1670 \mathrm{~mm}$ and 23.3 ${ }^{\circ} \mathrm{C}$ during the experimental period respectively. While AbiZARDI-Arua had the mean annual rainfall and temperature during the experimental period of $1379 \mathrm{~mm}$ and $24.4{ }^{\circ} \mathrm{C}$ respectively. Rwebitaba ZARDI-Kabarole which is the third site; had the mean annual rainfall and temperatures of $1711.4 \mathrm{~mm}$ and $20.5^{\circ} \mathrm{C}$ respectively during the experimental period. Based on the altitude, NaCRRI, Abi-ZARDI and Rwebitaba ZARDI-Kabarole were considered as low altitude,
Table 1: Genetic materials and their characteristics

\begin{tabular}{llll}
\hline Codes & Genotypes $(G)$ & Pedigree & Characteristics \\
\hline G7 & NASE 3 & TMS/30572 & High flowering and seed set \\
G4 & NASE 12 & MH95/0414 & High flowering and seed set \\
G5 & NASE 14 & MM96/4271 & High flowering and seed set \\
G6 & NASE 2 & TMS/30337 & High flowering and no seed \\
G8 & TME 204 & TME 419 & Poor flowering and seed set \\
G1 & ALADO & Landrace & Hardly flower most of the time \\
& - ALADO & & \\
G2 & BAO & Landrace & Hardly flower most of the time \\
G3 & MAGANA & Landrace & Hardly flower most of the time \\
\hline
\end{tabular}

Table 2: Geographical characteristics of the experimental sites used for evaluation of cassava floweing and seed ste related traits

\begin{tabular}{|c|c|c|c|c|c|}
\hline Codes & $\begin{array}{l}\text { Location } \\
\text { (E) }\end{array}$ & Latitude & Longitude & $\begin{array}{l}\text { Altitude } \\
*(\text { m.a.s.L })\end{array}$ & $\begin{array}{l}\text { Cropping } \\
\text { seasons }\end{array}$ \\
\hline E1 & $\begin{array}{l}\text { Abi- } \\
\text { ZARDI }\end{array}$ & $\begin{array}{l}301^{\prime} 12 \\
\text { North }\end{array}$ & $\begin{array}{c}305^{\prime} 39^{\prime} \\
\text { East }\end{array}$ & 1,198 & Season 1 \\
\hline E2 & NaCRRI & $\begin{array}{l}05^{\prime} \\
\text { North }\end{array}$ & 32 61' East & 1,148 & Season 2 \\
\hline E3 & Rwebitaba & $\begin{array}{l}00^{\prime} 15 \\
\text { North } \\
\text { and } 10 \\
00^{\prime} \text { North }\end{array}$ & $\begin{array}{l}30000 \text { 'East } \\
31015 \text { 'East }\end{array}$ & 1,506 & Season 1 \\
\hline E4 & $\begin{array}{l}\text { Abi- } \\
\text { ZARDI }\end{array}$ & & & & Season 2 \\
\hline E5 & NaCRRI & & & & Season 1 \\
\hline E6 & Rwebitaba & & & & Season 2 \\
\hline
\end{tabular}

*M.a.s.L= Meter above sea level

mid-altitude and high altitude respectively in this study. These different altitudes were chosen so as to ascertain how different altitudes influence cassava genotypes performance on flowering and seed set related traits response, since different altitudes have differences in climatic conditions such as rainfall and temperature.

\section{Soil sampling and analysis of the three environments}

Soil was sampled from all the sites. The sampling was carried out from middle and each corner of each replicate using a hand auger at approximately $30 \mathrm{~cm}$ of depth (USDA, 2002). For each replicate, soil samples were carefully and thoroughly mixed in a plastic bucket, until a homogeneous sample was obtained. Each homogeneous sample was packed in a new paper bag, labelled twice and shipped to Cornell University, Nutrients Analysis Laboratory (CNAL) in U.S.A. Soil was analyzed for most of the very essential soil nutrients. The purpose was to check the status of the soil nutrients of the selected experimental sites and their effects on cassava flowering and seed set traits.

\section{Experimental Procedures}

The experimental genotypes were established in randomized complete block design (RCBD), with three 
replications. Eight plots, forty-nine (49) planting materials per plot of $6 \mathrm{mx} 6 \mathrm{~m}$, with the spacing of $1 \mathrm{mx} 1 \mathrm{~m}$ between plants and $2 \mathrm{~m}$ between plots. In order to ensure uniformity in the physiological condition of the planting materials (stakes) and to minimize the variation during field establishment, the planting materials were cut into a uniform length $(20-30 \mathrm{~cm})$ from middle semi-woody parts of the cassava genotypes stems. The experimental plots were maintained weed free until harvest at 12 months under rain-fed conditions without any fertilizers applications and spraying of pesticides.

\section{Data collections}

Traits evaluated were number of branching levels, number of female and male flowers, number of fruits and seed set. The data were collected per genotypes from 1.5 month after planting (MAP) at the interval of one month. Cassava ontology protocol of investigating cassava flowering and seed set related traits was adapted from the cassava-base (Fernandez-Pozo et al., 2015). Inner five rows of each experimental plot which constituted a net plot of 25 plants were considered during every data collection point and out of the 25 plants, a randomly selected representative branches of the cassava plant within each plot were systematically followed up to the end of data collection point as adapted from cassavabase (Fernandez-Pozo et al., 2015). Branching level trait was scored by exhaustive counting of the actual number of levels of branching at harvest per plant per plot, while, male and female flowers and fruits set traits were scored by exhaustive counting of all male and female flowers and fruits set per each branching levels per plant per plot respectively. In most cases in cassava, more than one branch is found per plant but normally, one is randomly selected. For seed set, the data was scored by exhaustive counting of the number of seed formed from the fruits after pollination and collected per plant per plot.

Temperature and rainfall data were recorded during the experimentation period as well as soil nutrient profile of the fields prior to the planting of the experiments. The temperatures, rainfall and soil nutrients data were collected to ascertain the interaction effect of those different levels of variables on the performances of cassava genotypes based on flowering and seed set related traits.

\section{Data analysis}

Genstat twelve edition 12.1 (PC/Windows VISTA) 20 September 2016 was used for combined analysis of variance (ANOVA) over environments and AMMI model analysis of variance using the following model: $\mathrm{Y}_{\mathrm{ge}}=\mu+\alpha_{\mathrm{g}}+\beta_{\mathrm{e}}+$ $\sum \lambda_{\mathrm{n}} \gamma_{\mathrm{gn}} \delta_{\mathrm{en}}+\varepsilon_{\mathrm{ge}}$ where: Yge $=$ trait value of genotype $(\mathrm{g})$ in environment (e), $\mu$ = grand mean, $\alpha g$ = genotype deviation from the grand mean, $\beta \mathrm{e}=$ environment deviation from the grand mean, $\mathrm{N}=$ number of interaction principal components (IPC) considered, $\lambda \mathrm{n}=$ singular value for the IPC $\mathrm{n}, \gamma \mathrm{gn}=$ the element of eigenvector for genotype $(\mathrm{g})$ and IPC $\mathrm{n}, \delta \mathrm{en}=$ the element of eigenvector for environment (e) and IPC $\mathrm{n}$ and
Ege $=$ random error (Gauch et al., 2008; Gauch, 2013). The IPCs were extracted from AMMI model. The AMMI analysis showed the mean squares for interaction principal component axis two (IPCA2) were non-significant for all traits evaluated except for female flower, fruits set and seed set traits. This gave a room for AMMI 1 model to be adopted as such, bi-plots of the IPC1 scores versus genotype and environment means were presented for measured traits.

The AMMI analyses were complemented with GGE bi-plot analysis. The first two principal components were used to obtain GGE bi-plots using the PBTools software (PBTools, 2014).To generate a bi-plot for visual analysis of multienvironment data, the singular values were partitioned into genotype and environment eigenvectors so that the GGE bi-plot model was rewritten as: Yge $=\mu+\beta \mathrm{e}+\mathrm{N} \sum \mathrm{n} \lambda_{\mathrm{n}} \gamma_{\mathrm{gn}} \delta_{\mathrm{en}}$ $+\varepsilon_{\text {ge }}$ where: Yge $=$ trait value of genotype $(\mathrm{g})$ in environment (e), $\mu$ grand mean, $\beta \mathrm{e}=$ environment deviation from the grand mean, $\mathrm{N}=$ number of interaction principal components (IPC) considered, $\lambda \mathrm{n}=$ singular value for the IPC $\mathrm{n}, \gamma \mathrm{gn}=$ the element of eigenvector for genotype (g) and IPC n, $\delta$ en $=$ the element of eigenvector for environment (e) and IPC $\mathrm{n}$ and gge $=$ random error (Gauch et al., 2008; Yan \& Kang, 2002).

Jointly, AMMI and GGE bi-plots were used to assess the performance and interaction patterns of genotypes and environments. Based on AMMI, a genotype with absolute IPCA1 value close to zero indicated low interaction and was considered to be stable while genotypes with greater absolute IPCA1 values were considered to have high sensitivity to environmental changes.

For stability analysis, it is possible to find a highly stable genotype that is not necessarily the best performer for traits of interest. To overcome this challenge, the genotype selection index (GSI) was adopted, which simultaneously selects for performance and stability (Farshadfar et al., 2013). For a given genotype, GSI is the sum of the corresponding rankings for mean performance and the AMMI stability value (ASV). The ASV is a measure of the stability of a genotype based on weighted IPCA1 and IPCA2 scores. Lower values of ASV indicate greater stability of the genotype (Purchase et al., 2000). For this study, IPCA2 axes were non- significant for branching level and male flower traits; therefore GSI was modified such that ranking was only based on IPCA1 as indicated below:

$$
\begin{gathered}
\text { GSI }_{\mathrm{g}}=\mathrm{RIPCAI}_{\mathrm{g}}+\mathrm{RY}_{\mathrm{g}} \text { (when IPCA1 is the only significant } \\
\text { IPCA score) GS1g = RIPCA1g + RIPCA2g + RYg (When }^{\text {IPCA1 \& } 2 \text { are significant). }} \\
\text { ESIe = RIPCA1e + RYe (when IPCA1 is the only } \\
\text { significant IPCA score). }
\end{gathered}
$$

ESIe $=$ RIPCA1e + IPCA2e + RYe $($ When IPCA1 \& 2 are significant). Where: GSIg = genotype stability index for genotype $(\mathrm{g})$ across locations for each trait, RIPCA1g \& IPCA2 $g$ = rank of genotype $(\mathrm{g})$ across environments based on IPCA1 \& IPCA2 respectively, and RYg = rank of genotype (g) based on mean performance across locations. Whereas, $\mathrm{ESIe}=$ environment stability index for environment (e) 
across genotypes for each trait, RIPCA1e \& IPCA2e = rank of environment (e) across genotypes based on IPCA1 \& IPCA2 respectively, and $\mathrm{RYe}=$ rank of environment $(\mathrm{e})$ based on mean performance across genotypes.

Genotypes and environments with the lowest GSI \& ESI for a given trait were considered to have the highest combined performance and stability (Farshadfar et al., 2013). Estimates of the variance components were used to calculate heritability of traits, such that: $H^{2}=\sigma^{2} g /\left(\sigma^{2} g+\sigma^{2}\right.$ gxe $\left.+\sigma^{2} e\right)$ Where: $\mathrm{H} 2$ = broad sense heritability, $\sigma^{2} \mathrm{~g}=$ variance component for genotype effects, $\sigma^{2}$ gxe $=$ variance component for interaction between genotype and environment and $\sigma^{2} \mathrm{e}=$ variance component for residual effects.

\section{RESULTS}

\section{Soil physiochemical properties of the three environments}

The soil chemical properties of the three environments (Abi-ZARDI, NaCRRI \& Rwebitaba) experimental fields' results are shown in Table 3. It revealed a lot of variability for some of the soil chemical properties, and varied within a range reported to be ideal for cassava production (Howeler, 1996).

Rwebitaba season one showed the highest amount of soil nutrients (1.2\% Soil moisture, 7.7\% soil organic matter, $11.3 \%$ Soil LOI, $24.8 \mathrm{mg} / \mathrm{kg}$ Sulfur, $0.0016 \mathrm{mg} / \mathrm{kg}$ Molybdenum, $44.7 \mathrm{mg} / \mathrm{kg}$ Aluminum, $13.9 \mathrm{mg} / \mathrm{kg}$ Iron) compared to the other five environments. It has also the lowest soil $\mathrm{pH}$ buffer of 11.3 among the evaluated environments. While Rwebitaba season two has 5.4 Soil pH, 5.8 Soil buffer, $2636.8 \mathrm{mg} / \mathrm{kg}$ calcium, $513.4 \mathrm{mg} / \mathrm{kg}$ Potassium, $449.1 \mathrm{mg} / \mathrm{kg}, 26.3 \mathrm{mg} /$ $\mathrm{kg}$ Phosphorus, $0.2 \mathrm{mg} / \mathrm{kg}$ Boron and $1.8 \mathrm{mg} / \mathrm{kg}$ Zinc as the highest soil nutrients compared to the other five evaluated environments. $\quad 0.05 \mathrm{mg} / \mathrm{kg} \quad$ Nickel, $\quad 0.0 \mathrm{mg} / \mathrm{kg}$ Copper, $0.00000 \mathrm{mg} / \mathrm{kg}$ Molybdenum, $14.6 \mathrm{mg} / \mathrm{kg}$ Aluminum and $14.4 \mathrm{mg} / \mathrm{kg}$ manganese as were also observed as the lowest soil nutrients in Rwebitaba season two compared to the other five environments (Table 3).

NaCRRI season one showed the $0.27 \mathrm{mg} / \mathrm{kg}$ Nickel and $0.22 \mathrm{mg} / \mathrm{kg}$ Copper as the highest amount of soil nutrients and $3.08 \mathrm{mg} / \mathrm{kg}$ Phosphorus and $1.06 \mathrm{mg} / \mathrm{kg}$ Iron as the lowest soil nutrients compared to the other five environments. While NaCRRI season two had only Manganese $(55.0 \mathrm{mg} / \mathrm{kg}$ ) as the highest soil nutrient compared to the other five evaluated environments, however, it also showed soil moisture $(0.6 \%)$ and Phosphorus $(3.4 \mathrm{mg} / \mathrm{kg})$ as the lowest soil nutrients compared to the other five environments (Table 3).

Thus, Abi-ZARDI showed $4.69 \%$ soil organic matter, 4.53 soil $\mathrm{pH}, 57.14 \mathrm{mg} / \mathrm{kg}$ Potassium and $0.26 \mathrm{mg} / \mathrm{kg}$ Zinc as the lowest soil nutrients in season one compared to the five evaluated environments. While Abi-ZARDI season two also showed soil organic matter (4.69\%), soil LOI (7.0), Magnesium (161.8mg/kg), Phosphorus (3.3mg/kg), Sulfur $(13.4 \mathrm{mg} / \mathrm{kg})$, Boron $(0.0 \mathrm{mg} / \mathrm{kg})$, Copper $0.0 \mathrm{mg} / \mathrm{kg})$ and Zinc $(0.3 \mathrm{mg} / \mathrm{kg})$ as
Table 3: Soil and weather characteristics of the six experimental sites

\begin{tabular}{lcccccc}
\hline & E1 & E2 & E3 & E4 & E5 & E6 \\
\hline $\mathrm{OM} \mathrm{\%}$ & 7.66 & 7.4 & 5.16 & 5.8 & 4.69 & 4.69 \\
$\mathrm{Soil} \mathrm{pH}$ & 4.61 & 5.4 & 4.82 & 4.8 & 4.53 & 4.6 \\
$\mathrm{Ca} \mathrm{mg/Kg}$ & 1985.6 & 2636.8 & 996.29 & 1034.6 & 865.25 & 919.9 \\
$\mathrm{~K} \mathrm{mg} / \mathrm{Kg}$ & 184.7 & 513.4 & 86.49 & 121.7 & 57.14 & 64.6 \\
$\mathrm{Mg} \mathrm{mg} / \mathrm{Kg}$ & 340.3 & 449.1 & 158.24 & 179.0 & 178.04 & 161.8 \\
$\mathrm{Ni} \mathrm{mg} / \mathrm{Kg}$ & 0.1 & 0.05 & 0.27 & 0.2 & 0.07 & 0.1 \\
$\mathrm{P} \mathrm{mg} / \mathrm{Kg}$ & 19.4 & 26.3 & 3.08 & 3.4 & 3.26 & 3.3 \\
$\mathrm{~S} \mathrm{mg} / \mathrm{Kg}$ & 24.8 & 18.0 & 18.08 & 20.7 & 13.7 & 13.4 \\
$\mathrm{~B} \mathrm{mg} / \mathrm{Kg}$ & 0.07 & 0.2 & 0.06 & 0.1 & 0.03 & 0.0 \\
$\mathrm{Cu} \mathrm{mg} / \mathrm{Kg}$ & 0.06 & 0.0 & 0.22 & 0.1 & 0.02 & 0.0 \\
$\mathrm{Mo} \mathrm{mg} / \mathrm{Kg}$ & 0.0016 & 0.000 & 0.0039 & 0.0002 & 0.001 & 0.001 \\
$\mathrm{Al} \mathrm{mg} / \mathrm{Kg}$ & 44.74 & 14.6 & 23.47 & 28.5 & 29.19 & 31.9 \\
$\mathrm{Mn} \mathrm{mg} / \mathrm{Kg}$ & 20.77 & 14.4 & 50.21 & 55.0 & 22.78 & 26.6 \\
$\mathrm{Fe} \mathrm{mg} / \mathrm{Kg}$ & 13.88 & 3.4 & 1.06 & 1.2 & 1.59 & 1.9 \\
$\mathrm{Zn} \mathrm{mg} / \mathrm{Kg}$ & 1.62 & 1.8 & 1.49 & 1.1 & 0.26 & 0.3 \\
$\mathrm{Rainfall}$ & 1711.4 & 1794.6 & 1670 & 1591.2 & 1549.4 & 1302.4 \\
$\mathrm{Minimum}$ & 25.9 & & 18.3 & & 19.4 & \\
$\mathrm{~T} .\left({ }^{\circ} \mathrm{C}\right)$ & & & & & & \\
$\mathrm{Maximum}$ & 16.1 & & 29.3 & & 30.8 & \\
$\mathrm{~T} .\left({ }^{\circ} \mathrm{C}\right)$ & & & & & & \\
\hline
\end{tabular}

$\mathrm{OM}=$ Soil organic matter, $(\mathrm{E} 1-\mathrm{E} 6)=$ Environments, $\& \mathrm{~T}=$ Temperature

the lowest soil nutrients compared to the other five evaluated environments (Table 3).

\section{Rainfall patterns of the three environments}

The changes in total monthly rainfall during the experimental period were given in figure 2 . The total monthly rainfall in Abi-ZARDI ranged between $288.4 \mathrm{~mm}$ (July) to $0.0 \mathrm{~mm}$ (January) in season one and $214.8 \mathrm{~mm}$ (July) to $0.0 \mathrm{~mm}$ (January) in season two. Low rainfall was observed between December up to May with total monthly rainfall ranging between $0.0 \mathrm{~mm}$ (January) to $80.0 \mathrm{~mm}$ (March) in season one, while in season two, low rainfall was observed from December up to March and in the month of August, with the total monthly rainfall ranging from $0.0 \mathrm{~mm}$ (Jan) to $83.7 \mathrm{~mm}$ (July) (Figure 2).

Meanwhile in NaCRRI, it ranged between $285.1 \mathrm{~mm}$ (December) to $0.0 \mathrm{~mm}$ (January) in season one and $285.1 \mathrm{~mm}$ (December) to $0.0 \mathrm{~mm}$ (January) in season two. Low rainfall were observed in January, February, and August with total monthly rainfall ranging between $0.0 \mathrm{~mm}$ (January) to $26.6 \mathrm{~mm}$ (August) in season one, however, in season two, low rainfall were observed from January, February, July, August, and September, with the total monthly rainfall ranging from $0.0 \mathrm{~mm}$ (January) to $94.9 \mathrm{~mm}$ (September) (Figure 2).

In Rwebitaba it ranged between $256.5 \mathrm{~mm}$ (November) to $0.0 \mathrm{~mm}$ (January) in season one and $256.5 \mathrm{~mm}$ (November) to $0.0 \mathrm{~mm}$ (January) in season two. Low rainfall were observed in December, January, February and July with total monthly rainfall ranging between $0.0 \mathrm{~mm}$ (January) to $76.8 \mathrm{~mm}$ (February) in season one, while in season two, low rainfall 

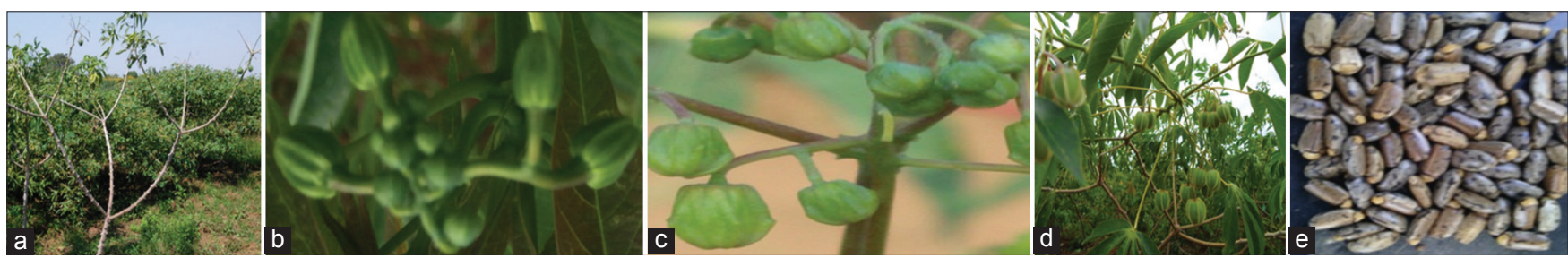

Figure 1: Cassava flowering and seed set related traits: Branching levels (a), Female flower (b), Male flowers (c), Fruits (d) and Seed (e).

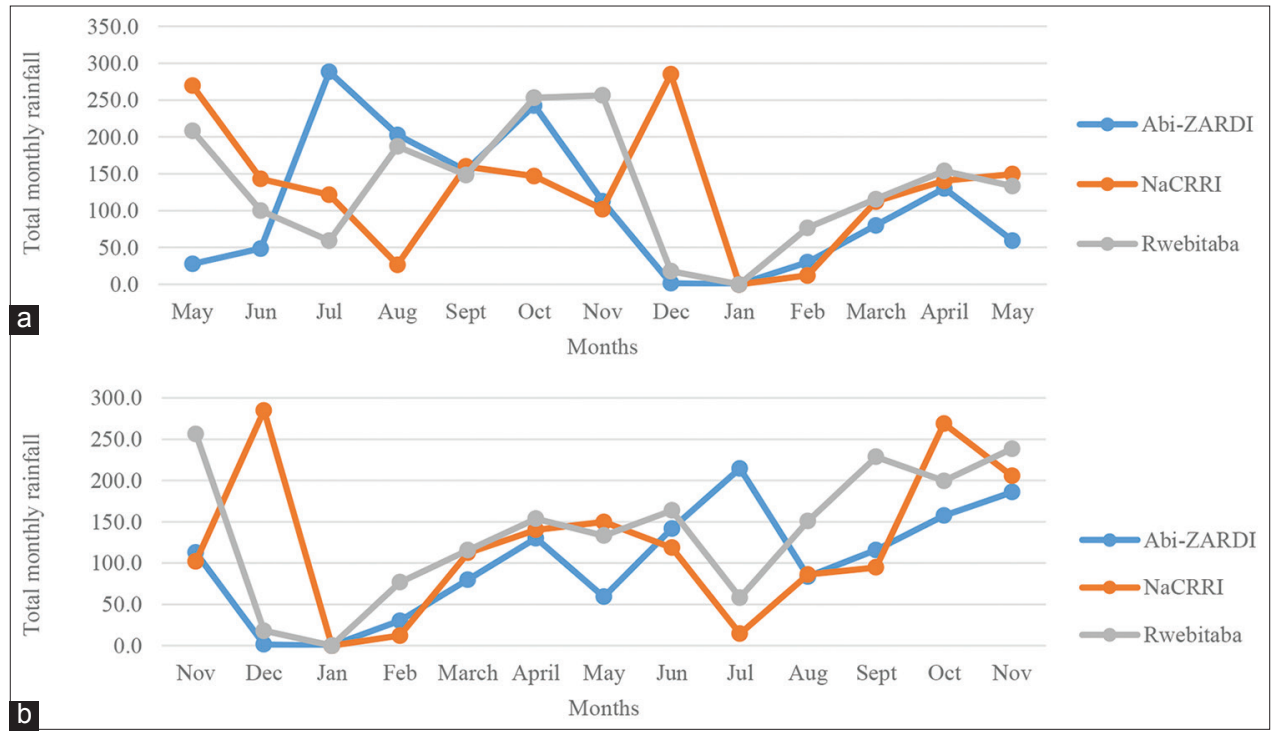

Figure 2: Rainfall for Abi-ZARDI, NaCRRI and Rwebitaba during two cropping seasons: May 2014/May 2015 (a) and Nov.2014/ Nov.2015 (b).

were observed from December, January, February and July with the total monthly rainfall ranging from $0.0 \mathrm{~mm}$ (January) to $76.8 \mathrm{~mm}$ (February) (Figure 2).

Thus, generally, rainfall distribution pattern was considerably moderate in season one with exception of NaCRRI than season two which was low. This has resulted into flowering initiation stage to coincide with wet period in season one in Abi-ZARDI and Rwebitaba, in contrast to NaCRRI season one and all the experimental sites in season two, where flowering initiation stage have coincided with the dry period. Therefore, season two have encountered drier periods than season one during the experimental period.

\section{Temperature ranges of the three environments}

Average monthly temperatures of the three environments ranges from $28.8^{\circ} \mathrm{C}$ to $23.1^{\circ} \mathrm{C}$, with growing period average temperature of $25.5^{\circ} \mathrm{C}$ in Abi-ZARDI, $25.9^{\circ} \mathrm{C}$ to $22.4^{\circ} \mathrm{C}$; with growing period average temperature of $24.1^{\circ} \mathrm{C}$ in NaCRRI and from $23.5^{\circ} \mathrm{C}$ to $19.8^{\circ} \mathrm{C}$, with growing period average temperature of 21.3 at Rwebitaba in season one (Figure 3). Meanwhile in season two it ranged from $28.8^{\circ} \mathrm{C}$ to $22.6^{\circ} \mathrm{C}$, with growing period average temperature of $24.4^{\circ} \mathrm{C}$ in Abi-ZARDI, $25.9^{\circ} \mathrm{C}$ to $22.0^{\circ} \mathrm{C}$; with growing period average temperature of $23.3^{\circ} \mathrm{C}$ in NaCRRI and from $23.5^{\circ} \mathrm{C}$ to $19.7^{\circ} \mathrm{C}$, with growing period average temperature of $20.8^{\circ} \mathrm{C}$ in Rwebitaba
(Figure 3). However, Abi-ZARDI have recorded higher temperature, followed by NaCRRI and Rwebitaba in both seasons respectively, likewise for growing degree temperature, Rwebitaba have performed below zero in contrast to NaCRRI and Abi-ZARDI respectively (Figure 3). Therefore, among the three environments based on the recorded temperature data, Abi-ZARDI could be classified as warm environment, NaCRRI as moderate environment and Rwebitaba a cool environment.

\section{Analysis of genotype by environment interaction (GEI)}

GEI analysis showed highly significant differences in flowering and seed set related traits among genotypes in season one, across the three environments $(\mathrm{P} \leq 0.001)$ for branching level. Significant differences for fruit set and seed set $(\mathrm{P} \leq 0.01)$ and for female flowers and male flowers $(\mathrm{P} \leq 0.05)$ were observed (Table 4). Environment effect was also significantly different for branching level $(\mathrm{P} \leq 0.05)$, although, for female flower, male flower, fruit set, and seed set were non-significant (Table 4). However, there were highly significant difference of genotypes by environments $(\mathrm{G} \times \mathrm{E})$ interaction effects for fruits set $(P \leq 0.001)$, seed set $(P \leq 0.001)$ and female flower $(P \leq 0.001)$ and significant differences of male flower $(\mathrm{P} \leq 0.01)$ and branching level $(\mathrm{P} \leq 0.05$ (Table 4). Highly significant differences in flowering and seed set related traits among genotypes in season two, across the three environments $(\mathrm{P} \leq 0.001)$ for all 
the evaluated cassava flowering and seed set related traits were observed (Table 4). There were also significant differences $(\mathrm{P} \leq 0.05)$ of environment effect for male flower and fruits set traits, although, for female flowers, seed set and branching level were non-significant (Table 4). However, G x E interactions effect were significantly different for fruits set $(\mathrm{P} \leq 0.01)$ and seed set $(\mathrm{P} \leq 0.01)$, but non-significant for branching level, female flowers, and male flowers (Table 4).

\section{AMMI bi-plot analysis}

Combined AMMI analysis of cassava flowering and seed set related traits of eight selected cassava genotypes tested across six environments showed highly significant differences $(\mathrm{P} \leq 0.001)$ among genotypes for all the evaluated traits except for fruits set and seed set traits which were non-significant $(\mathrm{P} \leq 0.05)$. The results also showed highly significant differences between environments for fruits and seed set $(\mathrm{P} \leq 0.001)$, for male flowers $(\mathrm{P} \leq 0.01)$, and non-significant differences for branching level and female flowers $(\mathrm{P} \leq 0.05)$ (Table 5). However, the genotype by environment ( $\mathrm{G} \times \mathrm{E}$ ) interactions were highly significant $(\mathrm{P} \leq 0.001)$ for branching level, female flowers, fruits set and seed set traits and very significant $(P \leq 0.01)$ for male flowers (Table 5). The interaction principal component axis one (IPCA1) MS was highly significant $(P \leq 0.001)$ for all the

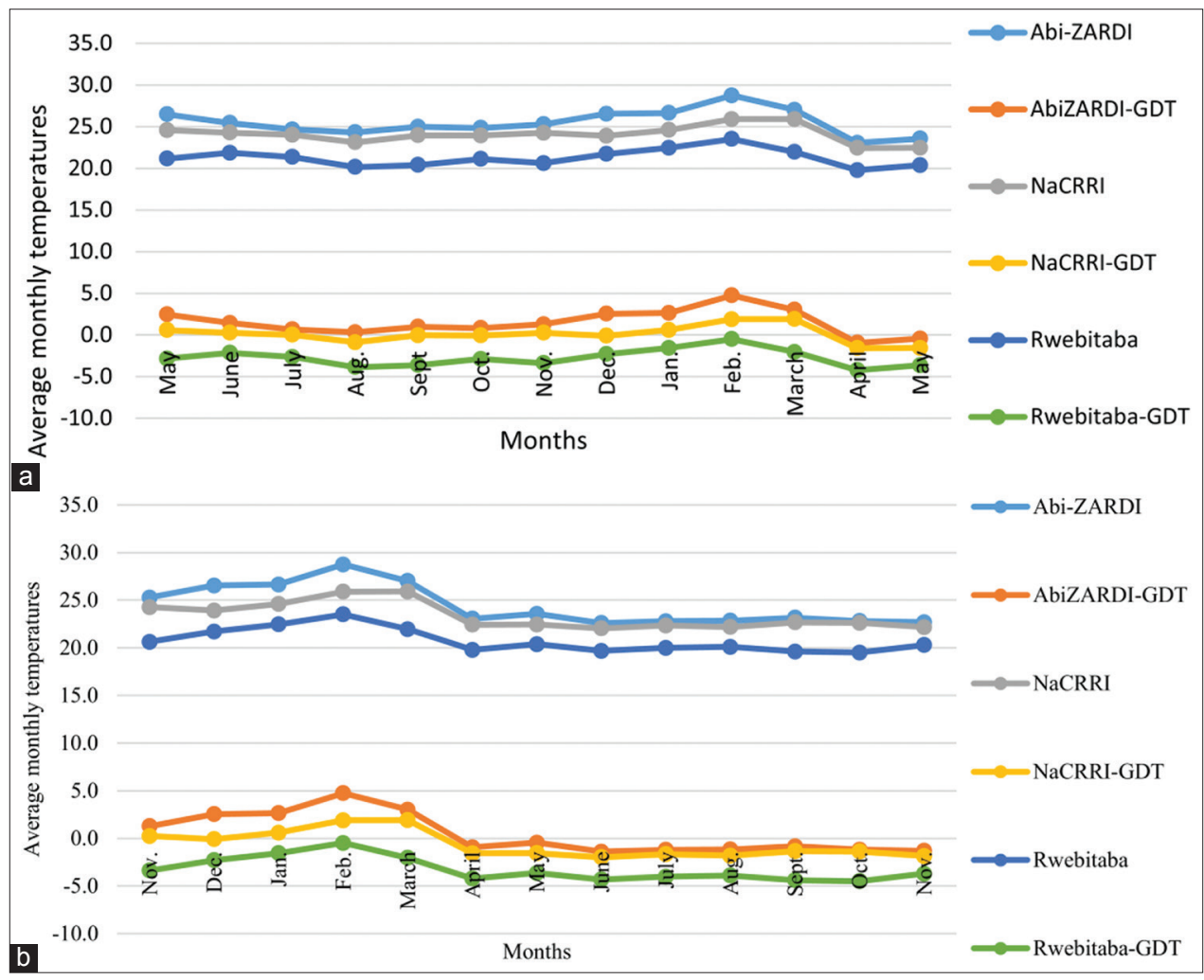

Figure 3: Temperatures and growing degree temperatures for Abi-ZARDI, NaCRRI and Rwebitaba during two cropping seasons: May 2014/May 2015 (a) and Nov.2014/Nov.2015 (b).

Table 4: Means squares (MS) of flowering and seed set related traits of 8 selected cassava genotypes tested within one season across three environments in Uganda

\begin{tabular}{|c|c|c|c|c|c|c|c|c|c|}
\hline \multirow[b]{2}{*}{$\begin{array}{l}\text { Sources of } \\
\text { Variation }\end{array}$} & \multirow[b]{2}{*}{ DF } & \multicolumn{4}{|c|}{ Mean squares (Season one) } & \multicolumn{4}{|c|}{ Mean squares (Season two) } \\
\hline & & $\begin{array}{c}\text { Branching } \\
\text { Level }\end{array}$ & $\begin{array}{l}\text { Female } \\
\text { Flowers }\end{array}$ & $\begin{array}{c}\text { Male } \\
\text { Flowers }\end{array}$ & Fruits & $\begin{array}{c}\text { Branching } \\
\text { Level }\end{array}$ & $\begin{array}{l}\text { Female } \\
\text { Flowers }\end{array}$ & $\begin{array}{c}\text { Male } \\
\text { Flowers }\end{array}$ & Fruits \\
\hline Environment (E) & 2 & $1.54^{*}$ & $0.226 \mathrm{~ns}$ & $0.56 \mathrm{~ns}$ & $0.073 \mathrm{~ns}$ & $0.38 \mathrm{~ns}$ & $0.09 \mathrm{~ns}$ & $0.44^{*}$ & $0.175^{*}$ \\
\hline Rep/E & 6 & $0.19 \mathrm{~ns}$ & $0.085 \mathrm{~ns}$ & $0.16 \mathrm{~ns}$ & $0.019 \mathrm{~ns}$ & $0.63 \mathrm{~ns}$ & $0.046 \mathrm{~ns}$ & $0.07 \mathrm{~ns}$ & $0.025 \mathrm{~ns}$ \\
\hline Genotype (G) & 7 & $8.11^{* * *}$ & $0.77^{*}$ & $1.085^{*}$ & $1.435^{* *}$ & $12.2 * * *$ & $1.29 * * *$ & $1.74^{* * *}$ & $1.45^{* * *}$ \\
\hline GXE & 14 & $0.57^{*}$ & $0.203^{* * *}$ & $0.333 * *$ & $0.237 * * *$ & $0.84 \mathrm{~ns}$ & $0.069 \mathrm{~ns}$ & $0.16 \mathrm{~ns}$ & $0.099 * * *$ \\
\hline Residual & 42 & 0.31 & 0.046 & 0.115 & 0.043 & 0.48 & 0.06 & 0.14 & 0.03 \\
\hline$\% \mathrm{CV}$ & & 14.3 & 16.6 & 16.8 & 21.2 & 18.9 & 20.3 & 20.6 & 27.7 \\
\hline $\mathrm{BSH}$ & & 0.93 & 0.737 & 0.693 & 0.835 & 0.932 & 0.933 & 0.907 & 0.93 \\
\hline
\end{tabular}

$(1)^{*}, * *$, and ${ }^{* * *}$ represent significance level at $\mathrm{P} \leq 0.05, \mathrm{P} \leq 0.01$ and $\mathrm{P} \leq 0.001$ respectively, ns = not significant. (2) Rep/ E: Replication within Environment.

(3) $\% \mathrm{CV}=$ percentage coefficient of variation, (4) $\mathrm{BSH}=$ Broad Sense Heritability on genotype mean basis across environments. 
Table 5: AMMI analysis of response of eight cassava genotypes to cassava flowering and seed set related traits evaluated across three environments for two seasons in Uganda

\begin{tabular}{|c|c|c|c|c|c|}
\hline \multirow{2}{*}{$\begin{array}{l}\text { Source of } \\
\text { Variations }\end{array}$} & \multirow[t]{2}{*}{ DF } & \multicolumn{4}{|c|}{ Means squares } \\
\hline & & $\begin{array}{c}\text { Branching } \\
\text { Level }\end{array}$ & $\begin{array}{l}\text { Female } \\
\text { flowers }\end{array}$ & $\begin{array}{c}\text { Male } \\
\text { Flowers }\end{array}$ & $\begin{array}{c}\text { Fruits } \\
\text { set }\end{array}$ \\
\hline Treatments & 47 & $3.56 * * *$ & $0.41 * * *$ & $0.64 * * *$ & $0.63 * * *$ \\
\hline Genotypes (G) & 7 & $18.71 * * *$ & $1.95 * * *$ & $2.62 * * *$ & $2.82 \mathrm{~ns}$ \\
\hline Environments( E) & 5 & $1.08 \mathrm{~ns}$ & $0.18 \mathrm{~ns}$ & $0.72 * *$ & $0.95 * * *$ \\
\hline $\mathrm{G} \times \mathrm{E}$ Interaction & 35 & $0.89 * * *$ & $0.13 * * *$ & $0.24^{* *}$ & $0.15^{* * *}$ \\
\hline IPCA 1 & 11 & $1.91 * * *$ & $0.27 * * *$ & $0.53 * * *$ & $0.24 * * *$ \\
\hline IPCA 2 & 9 & $0.67 \mathrm{~ns}$ & $0.12 *$ & $0.19 \mathrm{~ns}$ & $0.13 * * *$ \\
\hline Error & 15 & 0.27 & 0.03 & 0.05 & 0.09 \\
\hline $\begin{array}{l}\% \text { of Treatments SS } \\
\text { due to } G\end{array}$ & 7 & 63.74 & 55.85 & 70.18 & 59.77 \\
\hline $\begin{array}{l}\% \text { of Treatments SS } \\
\text { due to } E\end{array}$ & 5 & 2.63 & 3.77 & 20.24 & 14.4 \\
\hline $\begin{array}{l}\% \text { of Treatment SS } \\
\text { due to GEI }\end{array}$ & 35 & 15.14 & 18.92 & 19.71 & 15.61 \\
\hline $\begin{array}{l}\% \text { of GEI SS due to } \\
\text { IPCA } 1\end{array}$ & 11 & 67.56 & 65.48 & 70.18 & 50.39 \\
\hline $\begin{array}{l}\% \text { of GEI SS due to } \\
\text { IPCA } 2\end{array}$ & 9 & 19.42 & 24.3 & 20.24 & 22.48 \\
\hline
\end{tabular}

IPCA 1 \& IPCA 2: Interaction principal components axes, ${ }^{*}, * *$, and $* * *$ represent significance level at $\mathrm{P} \leq 0.05, \mathrm{P} \leq 0.01$ and $\mathrm{P} \leq 0.001$ respectively, ns $=$ not significant evaluated traits, as well as interaction principal component axis two (IPCA2) MS was highly significant $(\mathrm{P} \leq 0.001)$ for fruit set, very significant $(\mathrm{P} \leq 0.01)$ for seed set and significant $(\mathrm{P} \leq 0.05)$ for female flower trait, however, it was non-significant for branching level and male flower trait (Table 5). AMMI analysis also showed that the percentage (\%) of treatment sum of squares (SS) attributed to genotypes was higher than those due to environments or GEI for all the evaluated cassava flowering and seed set related traits (Table 5). The \% of treatments SS due to GEI was higher than that due to environments for all the evaluated cassava flowering and seed set related traits as well as $\%$ GEI due to IPCA 1 was three times more than that of IPCA 2 (Table 5).

\section{Genotypes and environments performances and stability}

Genotypes and environments stability based on branching level trait showed that, the stable but low branching levels genotypes were ALADO-ALADO and BAO contrast to NASE 12 which is relatively stable but yet with high branching levels, while unstable genotypes were Magana, NASE 14, NASE 2, NASE 3 and TME 204 respectively (Figure 4). The most stable and high performing environments based on branching level trait were NaCRRI season two, followed by Abi-ZARDI season one. While Rwebitaba season one and two were unstable and

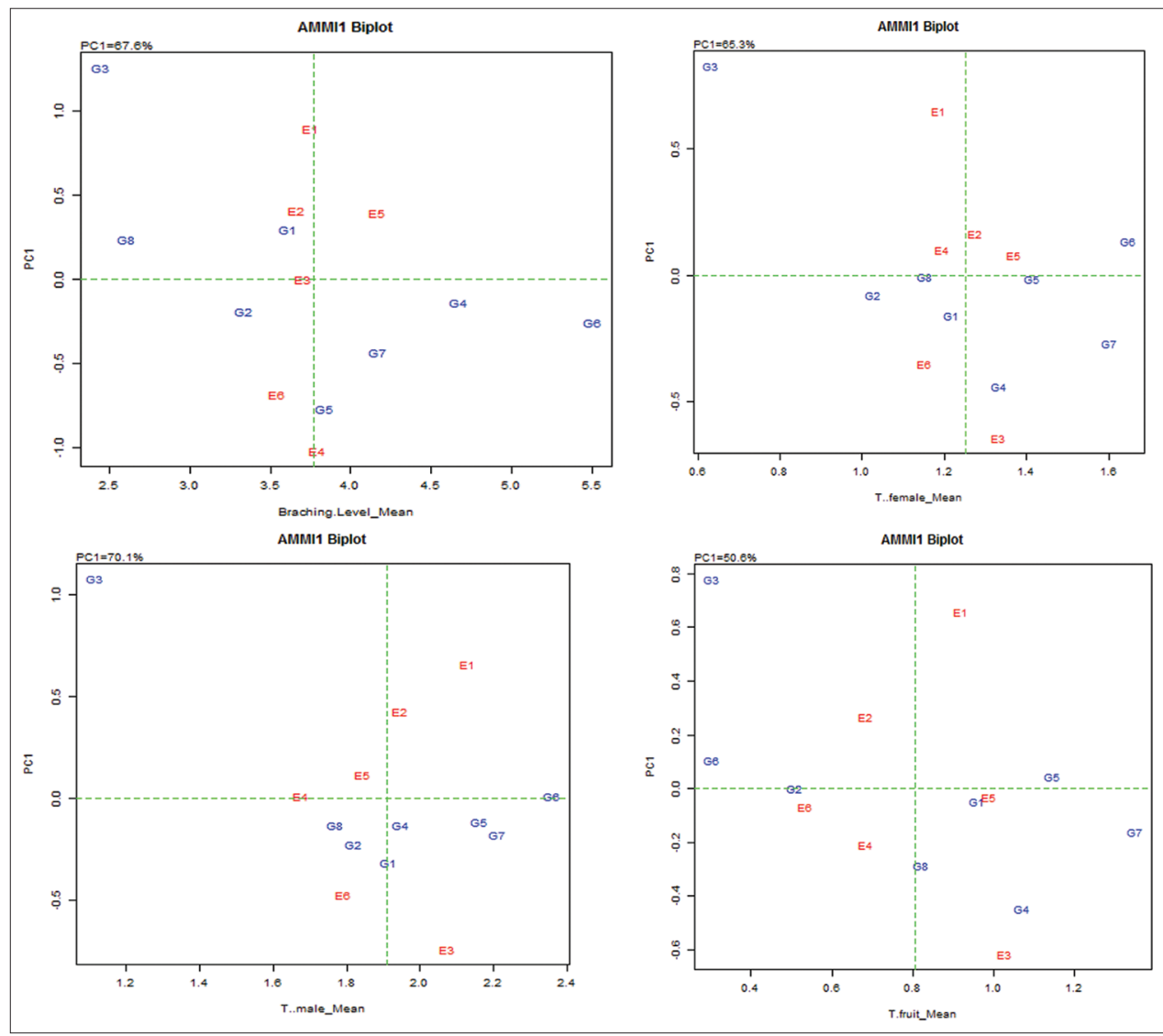

Figure 4: AMMI 1 bi-plots based on branching level, female flower, male flower and fruit set traits mean against PC1 scores for eight cassava genotypes evaluated in six environment in Uganda. E1=Abi-ZARDI-season one, E2=Abi-ZARDI-season two, E3=NaCRRI-season one. 
high as well as low performing environments respectively. Thus, the most stable and low performing environments were NaCRRI season one and Abi-ZARDI season two (Figure 4).

While for number of female flower trait, the stable but low number of female flowers genotypes were TME 204, ALADOALADO and BAO respectively, contrast to NASE 14 which is stable with high number of female flowers, while unstable genotypes were Magana, NASE 2, NASE 3, NASE 12 and BAO respectively (Figure 4 ). The most stable and high performing environments based on number of female flower per genotype were Rwebitaba season one, followed by Abi-ZARDI season two. While NaCRRI and Abi-ZARDI both in season one were unstable and high as well as low performing environments respectively (Figure 4).

Meanwhile for number of male flower trait, the stable but yet with high number of male flower genotype were NASE 2, ALADO-ALADO, NASE 12 and NASE 14 respectively, while unstable genotypes were Magana, NASE 3, BAO and TME 204 respectively (Figure 4). The most stable and high performing environments based on number of male flower per genotype was Abi-ZARDI season two, while NaCRRI and Abi-ZARDI both in season one were the most unstable, yet high performing environments. However, NaCRRI season two and Rwebitaba season one were stable but low performing environments. Rwebitaba season two was the most unstable and low performing environment among all the evaluated environments (Figure 4).

However, for fruit set trait, the stable but low fruits set genotypes were BAO and NASE 2, while the stable but yet with high number of fruits set genotypes were TME 204, ALADOALADO and NASE 14 respectively. Meanwhile unstable genotypes were Magana, NASE 12, and NASE 3 respectively (Figure 4). The most stable and high performing environment based on number of fruits set per genotype was Rwebitaba season one, while unstable and low performing environment was Rwebitaba season two. However, unstable but high performing environments were NaCRRI and Abi-ZARDI; both in season one, while unstable but low performing environments were NaCRRI and Rwebitaba; both in season two (Figure 4).

\section{Discriminating ability, Representativeness, and Relationships of test Environments}

The polygon view of the GGE bi-plot showed G3 (Magana), G8 (TME 204), G5 (NASE 14) and G6 (NASE 2) as the vertex genotypes for branching level trait, and Rwebitaba season one and Abi-ZARDI season two for NASE 14 and NaCRRI season one for NASE 2 as the mega environments based on performance of branching level trait respectively (Figure 5). While, for female flower trait the vertex genotypes were G2

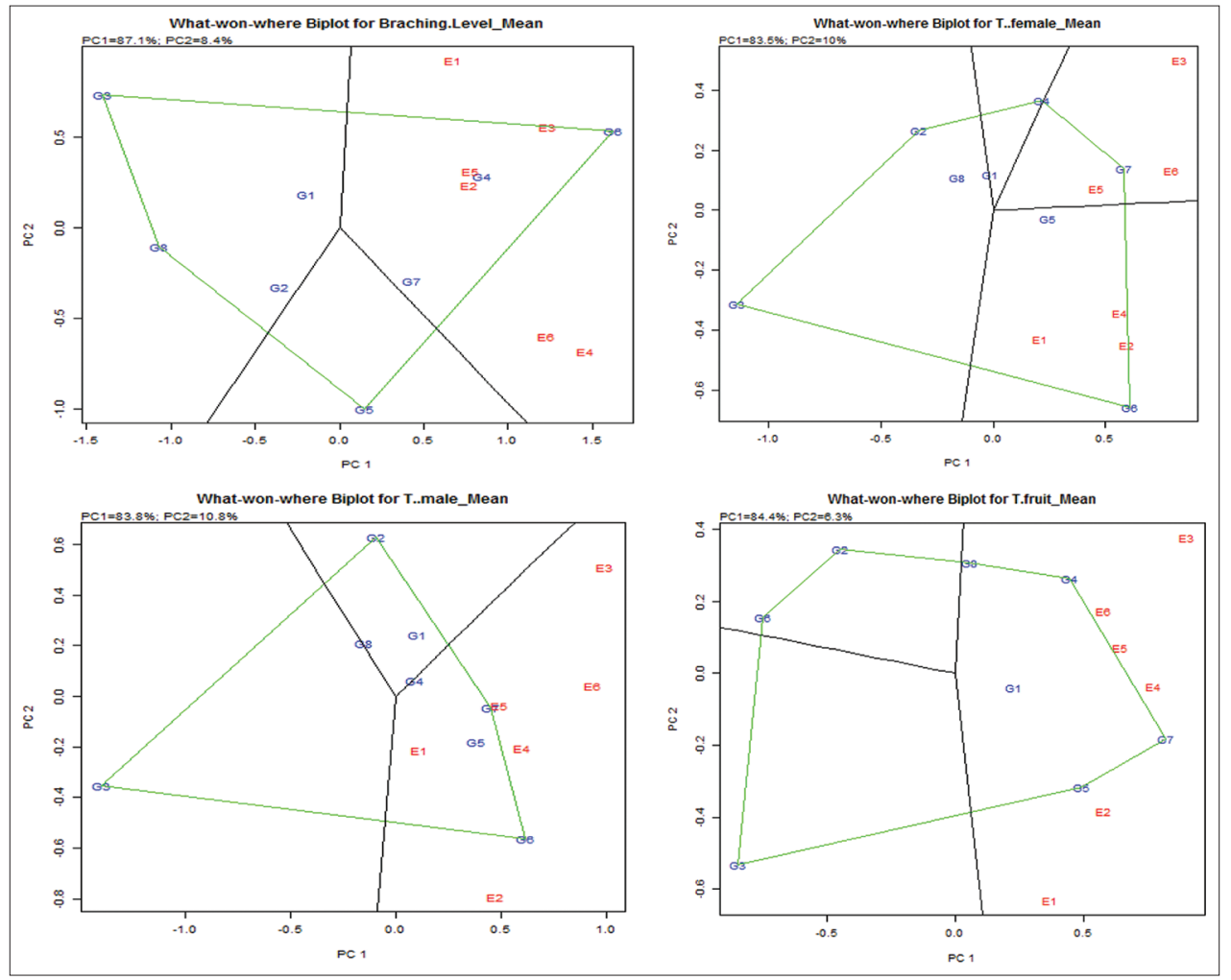

Figure 5: Polygon view of the GGE bi-plot (J) based on symmetrical scaling for which win where pattern of genotypes and environments for branching level, female flower, male flower and fruits set traits against PC1 scores for eight cassava genotypes evaluated in six environments in Uganda. E1=Abi-ZARDI-season one, E2=Abi-ZARDI-season two, E3=NaCRRI-season one, E4=NaCRRI-season two, $E 5=$ Rwebitaba-season one and E6=Rwebitaba-season two. G1=ALADO-ALADO, G2=BAO, G3=Magana, G4=NASE 12, G5=NASE 14, G6=NASE 2, G7=NASE 3, G8=TME 204, and PC1 \& 2 = Principal component. 
(BAO), G3 (Magana), G6 (NASE 2), G7 (NASE 3) and G4 (NASE 12), and the mega environments were Rwebitaba season one and two for NASE 3, and Abi-ZARDI season two for NASE 2 (Figure 5). Meanwhile for male flower trait, they were G2 (BAO), G3 (Magana), G6 (NASE 2) and G7 (NASE 3 ), and the mega environments were Rwebitaba season one for NASE 3, and NaCRRI season two for NASE 14 and AbiZARDI season two for NASE 2 (Figure 5). And for fruit set trait, it includes G2 (BAO), G6 (NASE 2), G3 (Magana), G5 (NASE 14), G7 (NASE 3), G4 (NASE 12) and G8 (TME 204) and the mega environments were Abi-ZARDI season two for NASE 14, and NaCRRI season two for NASE 3 and Rwebitaba season two for NASE 12 (Figure 5).

\section{DISCUSSION}

The significant G x E interaction effects on branching level, female flowers, fruits set and male flowers traits respectively implied that these traits were influenced by $\mathrm{G} x \mathrm{E}$ interactions that may be due to the presences or absences of one of the biotic and abiotic factors in those individual environments. Lynch and Walsh (1998), reported that G x E interaction influence traits expression such that individual with identical genotypes can have different phenotypes when exposed to different environments. This creates a need for testing genotypes in multi-environmental trials in order to identify generally and specifically adapted genotypes.

Given the limitations associated with analysis of variance, the detected significant $G \times \mathrm{E}$ interaction effects on the cassava evaluated traits requires use of multivariate approaches for visualization of the effects on the genotypes and environments. As such, AMMI analysis revealed adequate genetic variability being manifested by the predominance of genetic variation among genotypes over variations among environments and variations due to the interaction between genotypes and environments for all the evaluated cassava flowering and seed set related traits. The variations were justified by AMMI results of the percentage (\%) of treatment sum of squares (SS) attributed to genotypes which was higher than that due to environments or GEI for all the evaluated cassava flowering and seed set related traits. This implied that, the selected genotypes could be planted in any of the selected environments for flower and seed set production for breeding programmes. For breeding purposes, this will help save a lot of resources such as money and time which will be wasted for spreading breeding nurseries in more than one location, but rather concentrate on one location which will give efficient and effective results.

The percentage of GEI due to IPCA1 was three times more than that of IPCA2. The relatively large percent for the GEI over environments effects indicated that IPC1 axis captured much of variations associated with the $\mathrm{G} \times \mathrm{E}$ interaction effects as observed by their significant mean squares for all the evaluated traits. The non-significant IPCA2 plus the subsequent axis for branching level and male flower trait indicate that they captured largely random noise. Gauch (1992) reported that significance IPCA1 and subsequent axes in AMMI captured interaction exclusively in a monotonic sequence that decreases from the first to the last components. Thus, the significance IPCA1 scores explaining the range between $50.39 \%$ (fruits set) to $67.56 \%$ (branching level) sufficed for visual assessment of the genotypes and environment performances and their interactions in the AMMI bi-plots. However, the significant environmental effects on branching level, male flower and fruits set as well as fruits set and male flowers in both conventional ANOVA in two seasons and AMMI analysis respectively; results indicated that the selected environments were different from each other, and the detected difference could be attributed to biotic and abiotic factors such as difference in rainfall quantity and distribution pattern, temperature, edaphic factors and relative humidity. This has been confirmed by a lot of variability for some of the soil chemical properties, differences in rainfall distribution, pattern and temperature difference of the three study sites.

Rwebitaba had more soil fertility than NaCRRI and AbiZARDI as indicated by soil analysis results which was showing high amount of most of the soil chemical properties compared to the other two environments. Among the three environments, Abi-ZARDI could be classified as warm environment, NaCRRI as moderate environment and Rwebitaba as cooler environment based on temperature regime, although rainfall quantity and distribution pattern was fluctuating among the three environments without clear trends. However, this could form the basis for initiation of establishment of breeding nurseries for good progress on genetic improvement of cassava through hybridization. Because flower induction, opening of matured flowers, drying of fruits depend on timing of the available environmental conditions (Ceballos et al., 2004; Olasanmi et al., 2014). Also as it was reported by Beverley (2007) that, extremes cases of stress causes flower induction, and excessive or absence of certain soil nutrients trigger a stress response that promote flowering (Miyazaki et al., 2014). For example, low nitrate levels in the soil can accelerate flowering (Liu et al., 2013).

Therefore, the relatively low proportions of the variation partitioned to the environmental effect, indicated that cassava flowering and seed set related trait; although been influenced mainly by genetic make-up at the prevailing environmental conditions also have minimal environmental influences like other quantitative traits. Thus, for the cassava flowering and seed set related traits that exhibited highly significant $\mathrm{G} \times \mathrm{E}$ interaction, the genotypes have to be evaluated in diverse multiple environments in order to achieve reliable environments. The significant differences of environment effect for branching level trait in season one than in season two as well as significant difference of environment effect for male flower and fruits set in season two than in season one could be attributed to the effect of the fluctuating environmental conditions such as temperature, rainfall, 
edaphic factors and other unmonitored factors in this study. As reported by Keating et al. (1982), Simwambana (1993) and Alves (2002) that, cause cassava flower induction and seed set are controlled by different levels of multi-environmental factors such as temperature, rainfall fluctuation, soil moisture availability, relative humidity, and day length.

For enhancement of cassava branching levels initiation, NaCRRI season two, followed by Abi-ZARDI season one were identified in this study as the most stable and high performing environments. The interchangeable reaction of those environments and seasons might be attributed to the fluctuation of availability of different levels of multi-environmental factors during the cropping seasons at respective study sites. This create problem of decision making of which environment to consider, but it can be ratify by doing more trials and involving other environments. The favorable environment for enhancing female flower, fruit set in cassava was identified as Rwebitaba in season one. This could be attributed to low temperature, moderate rainfall and distribution pattern as well as higher amounts of most of the soil chemical properties (such as calcium, potassium, magnesium, phosphorus, soil moisture and soil LOI \%). While Abi-ZARDI season two was identified as favorable for cassava male flowers which might be due to attribute of warm environment. However based on stability and environment performances, NaCRRI season one followed by Abi-ZARDI season two could be considered as unfavorable environments for enhancing cassava branching levels. While Abi-ZARDI season one could be unfavorable environment for cassava female flower and Rwebitaba season two for cassava male flowers and fruits set. This could be due to inappropriate timing of availability of different levels of multi-environmental factors with cassava flowering and seed set related traits induction and initiation at the respective cropping seasons at the study sites.

The selected cassava genotypes varied in their ability to flower and set seed under the prevailing climatic conditions across the three different environments in the two seasons, although there were individual differences. This indicated that, the selected cassava genotypes have adequate genetic diversity for flowering and seed set which might have been acquired through periodical cross pollination and geographical adaptability. This is important for breeders because it show the possibility of the selected cassava genotypes to be used for flowering and seed set production and breeding program in a studied environment. This result was in agreement with [25] who did similar work on the study of the reproductive characteristics of nine cassava accessions in one environment. This finding can be used to alleviate problem of nonsynchronized cassava flowering and inability of using cassava genotypes with desirable characteristics in cassava breeding programmes ([26].

The four categories of cassava genotypes based on flowering and seed set attributes, which include genotypes with high flowering and seed set, high flowering and no seed set, poor flowering and seed set and hardly flower most of the time genotypes were purposely evaluated in six diverse environments to ascertain how the different flowering attributes may react in the different selected environments. Thus, the genotypes performance results showed that, the selected cassava genotypes differed in all studied flowering and seed set related traits performances across environments and seasons by producing flowers and seed set at different timing and different quantities. This indicated, the selected cassava genotypes have different genetic capability and timing of flowering and seed set. This was in agreement with the previous authors who reported that there are a lot of variation in cassava flower production and seed set, which is because some cassava genotypes flower early or late, others have attributes of poor, moderate or profuse with poor or high fruit setting (Jennings \& Hershey, 1992; Ravi \& Ravindran, 2006). This implied that, all the four categories can be used for cassava hybridization but with cautions of good timing for the purpose of synchronization of the flowering.

So, based on the evaluated cassava flowering and seed set traits, although; the poor flowering and seed set category of the selected cassava genotypes (ALADO-ALADO, BAO, Magana and TME 204) have shown considerable number of flowers and seed set, yet they have performed below the grand mean together with NASE 2 for fruit and seed set traits, with the exception of ALADO-ALADO for male flowers, fruit set and seed set traits which have performed together with the highly flowering and seeds set category of the selected cassava genotypes (NASE 12, NASE 3 \& NASE 14) above the grand mean. However, the failure of NASE 2 and Magana in setting seed at Rwebitaba in season two might be attributed to the effect of hail storm which occurred coinciding with the reproductive stage of the plant during experimental period. The difference in performance of these two categories might be attributed to the difference in genetic make-up of the selected categories of the cassava genotypes because all of them were subjected into the same levels of environments at the same time. This implied varieties within crop species can have different environment sensitivities that might have arisen through long adaptation to different growth environments or though breeding. For example, Schmalenbach et al. (2014) reported that, early flowering lines suffered a greater fitness cost than late flowering lines which eventually were able to recover when he performed a study on relationship between flowering time and drought stress in near isogenic and recombinant inbred lines constructed from two Arabidopsis ecotypes that differ in flowering times, by exposing them to mild drought stress to ascertain their response to drought stress.

Conclusively, since flowering and seed set related traits are environment and genotypes dependent (Alves, 2002; Chavarriaga-aguirre \& Halsey, 2005), there is a need to evaluate the poor flowering and seed set category further at more environments for specific and general environment adaptations as supported by Ceballos (2002) who stated that, for breeding purposes, clones have to be classified into 
different ecotypes so that breeders may take into account the flowering habits of the plants they wish to cross.

\section{CONCLUSION}

GEI is a differential phenotypic performance of genetically uniform genotypes across test environments. It occurs because different genotypes have different genetic potentials to adjust themselves to variable environments and causes one genotype to not win everywhere and always. In this study the selected environments were different from each other and adequate genetic variability have been manifested by the predominance of genetic variation among genotypes over variations among environments and variations due to the interaction between genotypes and environments for all the evaluated cassava flowering and seed set related traits.

Among the three environments, Abi-ZARDI could be classified as warm environment, NaCRRI as moderate environment and Rwebitaba as cooler environment based on temperature regime, although rainfall quantity and distribution pattern was fluctuating among the three environments without clear trends.

Rwebitaba season one followed by NaCRRI season two could be suggested as favorable environment for enhancing female flower, fruit set and branching level trait respectively in cassava. Meanwhile Abi-ZARDI and NaCRRI season one could be considered as unfavorable environment for cassava female flower and branching level trait respectively as well as Rwebitaba season two for cassava male flowers and fruits set.

Cassava flowering and seed set related traits are genetically controlled and also depend on prevailing environmental conditions where the trials are conducted. The identified stable environment will allow breeders to confidently establish breeding nurseries with more hope of improving cassava genotypes and expansions of cassava germplasm for enrollment for hybridization activities and genetic improvements programs. Therefore, it can be recommended that, since flowering and seed set related traits are environment and genotypes dependent, there is a need to evaluate the poor flowering and seed set category further at more environments for specific and general environment adaptations.

\section{ACKNOWLEDGEMENTS}

The authors are thankful and grateful to the technicians and staffs of Root Crops Program of National Crops Resources Research Institute, Uganda, Makerere University, Uganda and NextGen Cassava Breeding Project Phase one for provision of study materials, supervision and financial support of this research.

\section{REFERENCES}

Alves, A. A. C. (2002). Cassava botany and physiology. Cassava: Biology, Production and Utilization, 67-89. http://doi. org/10.1079/9780851995243.0000

Beverley, J. G. (2007). Understanding Flowers and Flowering An Integrated Approach, Oxford University Press. http://doi. org/10.1017/CBO9781107415324.004

Ceballos, H., Iglesias, C. A., Pérez, J. C., and Dixon, A. G. O. (2004). Cassava breeding: Opportunities and challenges. Plant Molecular Biology, 56(4), 503-516. http://doi.org/10.1007/ s11103-004-5010-5

Ceballos, H., Pérez Velásquez, J., Calle, F., Jaramillo O, G., Lenis Calderón, J., Morante, N., \& López, J. (2002). A new evaluation scheme for cassava breeding at CIAT. Centro Internacional de Agricultura Tropical (CIAT), Cassava Office for Asia. Retrieved from https://cgspace.cgiar.org/handle/10568/56112

Chavarriaga-aguirre, P., \& Halsey, M. (2005). Cassava (Manihot esculenta Crantz): Reproductive biology and practices for confinement of experimental field trials. Report prepared for the Program for Biosafety Systems. Washington, D.C: Program for Biosafety Systems.

Egesi, C., Cuambe, C., Rosero, A., Sanchez, T., Morante, N., Ceballos, H., \& Fregene, M. (2007). Genetic Mapping Of Delayed Post-Harvest Physiological Deterioration In Cassava In Backcross Derivatives Of Manihot. In Abstract in PAGXVI San Diego, CA P6.

Farshadfar, E., Rashidi, M., Jowkar, M. M., \& Zali, H. (2013). GGE biplot analysis of genotype $\times$ environment interaction in chickpea genotypes. European Journal of Experimental Biology, 3(1), 417-423.

Fernandez, G. C. J. (1991). Analysis of Genotype X Environment Interaction by Stability Estimates. Hortscience, 26(8), 947-950. https://doi.org/10.21273/HORTSCI.26.8.947

Fernandez-Pozo, N., Menda, N., Edwards, J. D., Saha, S., Tecle, I. Y., Stickler, S. R., Bombarely, A., Fisher-York, T., Pujar, A., Foerster, H., Yan, A., \& Mueller, L. (2015). The sol Genomics Network (SGN)From genotype to phenotypes to breeding. Nucleic Acids Research, 43, D1036-1041. https://doi.org/10.1093/nar/gku1195

Gauch, H. G. (1992). Statistical Analysis of Regional Yield Trials: AMMI analysis of factorial designs (pp. 278) Elsevier,New York.Chinese edition 2001.China National Rice Research Institute,Hangzhou, China.

Gauch, H. G. (2013). A simple protocol for AMMI analysis of yield trials. Crop Science, 53, 1860-1869. https://doi.org/10.2135/ cropsci2013.04.0241

Gauch, H. G., Piepho, H. P., \& Annicchiarico, P. (2008). Statistical analysis of yield trials by AMMI and GGE: further considerations. Crop Science, 48, 866-889. https://doi. org/10.2135/cropsci2007.09.0513

Howeler, R. (1996). Diagnosis of nutritional disorders and soil fertility maintenance of cassava. In G.T. Kurup, M. S. Polaniswami, V. P. Potty, G. Padmaja, S. Kabeerathumma and S.V. Pillaai, (Eds.), Tropical Tuber Crops: Problems, Prospects and future trategies, (pp. 181-193). New Delhi, India: Oxford and IBH Publishing Co. Pvt. Ltd.

Jaetzold, R., \& Schmidt, H. (1983). Farm Management Handbook of Kenya, East Kenya (Eastern and Coast Provinces), Ministry of Agriculture, German Agency for Technical Co-operation (GTZ), Nairobi. Vol. II/C.

Jennings, D. L., \& Iglesias, C. (2002). Breeding for Crop Improvement. Cassava: Biology, Production and Utilization, 149-166. http:// doi.org/10.1079/9780851995243.0000

Jennings, L. D., and Hershey, H. C. (1992). Progress in breeding cassava for adaptation to stress. Plant Breeding Abstracts, 62(8), 823-831.

Keating, B. A., Evenson, J. P., \& Fukai, S. (1982). Environmental 
effects on growth and development of cassava (Manihot esculenta Crantz.) I. Crop development. Field Crops Research, 5, 271-281. http://doi.org/10.1016/0378-4290(82)90030-2

Liu, T., Li, Y., Ren, J., Qian, Y., Yang, X., Duan, W., \& Hou, X. (2013). Nitrate or $\mathrm{NaCl}$ regulates floral induction in Arabidopsis thaliana. Biologia, 68, 215-222. http://doi.org/10.2478/ s11756-013-0004-x

Lynch, M., \& Walsh, B. (1998). Genetics and Analysis of Quantitative Traits. Sunderland, MA: Sinauer Associates.

Miyazaki, Y., Maruyama, Y., Chiba, Y., Kobayashi, M. J., Joseph, B., Shimizu, K. K., \& Satake, A. (2014). Nitrogen as a key regulator of flowering in Fagus crenata: Understanding the physiological mechanism of masting by gene expression analysis. Ecology Letters, 17(10), 1299-1309. http://doi.org/10.1111/ele.12338

Nunekpeku, W., Amoatey, H. M., Oduro, V., Klu, G. Y. P., Asare, D. K., \& Danso, K. E. (2013). Study of the reproductive characteristics of nine cassava accessions. West African Journal of Applied Ecology, (2013); 21(1), 135-143.

Olasanmi, B., Akoroda, M.O., Egesi, C., Okogbenin, E., \& Fregene, M. (2014). Cross-compatibility among six improved cassava (Manihot esculenta Crantz) varieties. Journal of Roots Crops, 40(1), 15-22.

PBTools. (2014). Biometrics and Breeding Informatics. PBGB Division. International Rice Research Institute Los Banos, Laguna.

Purchase, J. L., Hatting, H., and van Deventer, C. S. (2000). Genotype × environment interaction of winter wheat (Triticum aestivum L.) in South Africa: II. Stability analysis of yield performance. South African Journal of Plant and Soil, 17(3),101-107. http://dx.doi. org/10.1080/02571862.2000.10634878

Ravi, V., \& Ravindran, C. S. (2006). Effect of soil drought and climate on flowering and fruit set in cassava (Manihot esculenta Crantz). Advances in Horticultural Science, 20(2), 147-150.

Schmalenbach, I., Zhang, L., Reymond, M., \& Jiménez-Gómez, J. M. (2014). The relationship between flowering time and growth responses to drought in the Arabidopsis Landsberg erecta $\mathrm{x}$ Antwerp-1 population. Frontiers in Plant Science, 5, 609. http:// doi.org/10.3389/fpls.2014.00609

Simwambana, M. S. C. (1993). Environmental factors modifying the growth and flowering behaviour of four cassava cultivars in Nigeria.

Shaff, B., Makler, K. A., Price, W. J., \& Auld, D. L. (1992). Genotype X environment interaction effects on Winter Rapeseed yield and oil content. Crop Science, 32, 922-927. https://doi.org/10.2135/ cropsci1992.0011183X003200040017x

USDA. (2002). U. S. Department of Agriculture. Field Book for Describing and Sampling Soils. Natural Resources Conservation Service, (Vol.33). https://doi. org/10.1111/j.1600 0587.2009.05973

Yan, W., \& Kang, M. S. (2002). GGE Biplot Analysis: A Graphical Tool for Breeders, Geneticists and Agronomists. CRC Press, New York. 